\section{Life in Flats}

SIR,-Your leading article on life in flats (19 September, p. 661) rightly stresses the disadvantages for inhabitants of modern tower blocks, particularly for families with young children. It would, however, be quite wrong to think that these are the only rehoused families who suffer social and geographical isolation. It would also be quite wrong to draw any conclusions as to aetiology of their unhappiness or ill-health by studying families only in the new environment.

Published studies on the effect of rehousing on the health of the individual or family unit are few, but the major studies into the psychiatric aspects ${ }^{1-4}$ all agreed that the prevalence of neurotic illness was the same in new towns as in other comparable populations in older urban areas. It was further shown that individuals suffering with psychiatric symptoms attributable to the new environment were similarly troubled before rehousing, and would therefore be regarded as vulnerable personalities. My own study into the situation in Salford ${ }^{5}$ confirmed this latter finding.

While not in any way wishing to discourage the immediate implementation of the suggestions of the N.S.P.C.C. report ${ }^{6}$ which would undoubtedly improve the living conditions for young families, it would be quite wrong to draw any conclusions from the report as to the effect on health as opposed to happiness. - I am, etc.,

\section{A. W. Johnson.}

Hope Hospital,

REFERENCES

1 Wilner, D. M., Walkley, R. P., Schram, J. M.. Pinkerton, T. C., and Tayback. M., American Fournal of Public Health, 1960, 50. 55 .

2 Wilner, D. M., Walklev, R. P., Pinkerton, T. C. and Tayback. M. The Housing Environment and Family Life. Baltimore, Johns Hopkins Press, 1962.

3 Tavlor. Lord, and Chave, S., Mental Health and Environment. London, I ongmans, 1964

Hare, E. H.. and Shaw, G. K., Mental Health on a New Housino

5 Johnsin D A W., Medical Officer, 1970. Awaiting publication.

6 National Society for the Prevention of Cruelty to Children, Children in Flats: a Family Study. London, N.S.P.C.C., 1970.

\section{Medical Students and Smoking}

SIR,-Lord Macaulay would have relished Bynner's revelations ${ }^{12}$ that whereas (nearly) every schoolboy smoker knows that cigarettes cause bronchial cancer, only half the medical student smokers are similarly persuaded. In summarizing his survey Medical Students' Attitudes to Smoking Bynner ${ }^{2}$ cautiously concluded "the advice and information they received on the subject of smoking could be improved." More abrasively Godber ${ }^{3}$ deplored this evidence of "a regrettable failure in medical education." However, the surprise occasioned by this disturbing publication was not shared by all because the findings had been anticipated in 1961 when Anderson ${ }^{4}$ reported: “. . . barely one-third (of medical schools) have begun to give adequate instruction to students."

Seeking to assess, from the teaching side, whether these regrettable failures were being remedied, a six-point questionnaire was sent during 1969 to the clinical subdeans of the 28 medical schools in the United Kingdom, with the following replies:
(1) "In the selection of medical students is any note taken of their smoking habits?""No" in 26; "the fact is noted" by one "nicotine-stained fingers are frowned upon" by one;

(2) "At the beginning of their training are medical students who smoke advised to stop?"- - "Yes" in 8;

(3) "Are the full medical and social facts concerning the effects of smoking presented to all students in their first year of clinical training?"-."Yes" in 16;

(4) "Are students allowed to smoke in lectures?"- "No" in 21;

(5) "Are clinical teachers made aware of the influence their own smoking habits have upon their students?"- "No" in 16;

(6) "Are there any wards in the teaching hospital(s) where 'No Smoking' is permitted?"- "No" in 19.

Granted the implication that only answer (4) "should" be in the negative, 23 of the 28 medical schools recorded a score of halfmarks or less in this antismoking examina-

\section{New Review Body}

SIR,-It was with concern and disappointment that I read the Secretary's letter to the Secretary of State (Supplement, 19 September, p. 95). In this he outlines the profession's views concerning the new review body, but at no stage does he even mention superannuation or pension rights. This is al the more remarkable in view of the policy of the General Medical Services Committee, who passed on 13 August the following resolution: "We therefore consider it essential that superannuation contributions and pension rights be within the remit of the new Review Body." (Supplement, 22 August, p. 76.) Furthermore, an identical motion was unanimously agreed at the last meeting of the Compensation and Superannuation subcommittee.

The medical profession should be aware of the fact that its pensions are by present day standards totally inadequate, and that all attempts to remedy this have proved

\section{Claims for Expenses}

SIR,-I recently attended, as a nominee of the Royal College of Surgeons, an advisory appointments committee outside my region. After the meeting I was given a form to claim for travelling and subsistence and this was duly paid by the board. It then dawned on me that I might also be entitled to a fee under conditions quoted in the Supplement (18 July, p. 62). I therefore wrote to the board to inquire about this. I quote from the treasurer's reply:

"The fee was not included in the cheque for your travelling and subsistence expenses

\section{Decade of Doctors' Pay}

SIR,-Your tabled review of a "Decade of Pay Increases" (Supplement, 3 October, p. 3) highlights discrepancies which urge me to write in protest.

I find the present situation ludicrous. A hospital senior registrar-who has spent many financially unprofitable years in training who, invariably, has at least one of the higher diplomas; who is approaching consultant experience, skill, and tion. Unchanged, this indecisive educative public health.

One of Bynner's ${ }^{2}$ conclusions was that the students' attitudes might be changed if they could all be persuaded to read the Royal College of Physicians' Report. ${ }^{5}$ Is it too inands of Report will be placed in the country as required reading?-I am, etc.,

Musgrove Park Hospital,

JOHN ANDERSON.

\section{REFERENCES}

Bynner, J. M., The Young Smoker, p. 36. London, H.M.S.O., 1969

ynner, J. M., Medical Students' Attitudes Towards Sinarting. London, H.M.S.O., 1967.

the State of the Public of the Chief Medical Officer for 1968, Repor London, H.M. O 1969 .

Aerson, J. P., Manchester Medical Gazette, $961,40.104$.

and Health of Physicians of London, Smokin

largely unavailing. The last review body actually stated that it was concerned but could take no action, as this was outside its remit. It was in the light of this latter statement that the G.M.S.C. pressed for the inclusion of superannuation in the new remit, yet when Dr. Stevenson writes on the points to which he attaches "particular importance," the subject is totally ignored Why?-I am, etc.,

\section{R. A. Keable-Elliott.}

High Wycombe, Bucks

**The Secretary informs us that his letter to the Secretary of State for Social Services was in the precise terms directed by the Council after a full debate on the whole situation; and that the profession's negotiators have been instructed by the Council to press strongly for the inclusion of superannuation within the remit of a reconstituted review body.-ED., B.M.F.

as it is not the policy of the Board to make payment of a fee unless it is specifically claimed."

I can see only two reasons for this behaviour. The first is inefficiency, in that none of the board's officers warned me that I might also claim this fee. The words "the policy of the Board" seem to negate this, and $I$ am thus left with the other reason, a deliberate attempt to make money out of a consultant's ignorance of the regulations-I am, etc.

Southsea, Hants.

Nigel Cridland

responsibility-earns approximately $£ 2,000$ less than his contemporaries and juniors who are in general practice.

It is also strange that, not until he reaches his third year, does a senior registrar earn more than the maximum registrar earning. Why?-I am, etc.,

Dudley Road Hospital,

KenNeth S. STEWART. 